\title{
Socio-demographic and health characteristics of elderly individuals: support for health services ${ }^{1}$
}

\author{
Calíope Pilger ${ }^{2}$ \\ Mario Humberto Menon ${ }^{3}$ \\ Thais Aidar de Freitas Mathias ${ }^{4}$
}

This is a sectional epidemiological study including a household survey. It describes the socio-demographic and health conditions of elderly individuals residing in Guarapuava, PR, Brazil. The study's sample consisted of 359 elderly individuals enrolled in primary health care units in the city. Interviews were conducted from January to April 2010 using sections I and II of the Brazil Old Age Schedule questionnaire. The results revealed that most interviewees were women (64.3\%), health self-perception was considered 'good' by $54.6 \%$, and the most prevalent diseases were hypertension (34.9\%), diabetes mellitus $(12,4 \%)$ and arthritis/arthrosis (12.2\%). Most elderly individuals use dental prostheses (74.4\%) and $56.5 \%$ wear glasses or contact lenses. The conclusion is that knowledge concerning the social, demographic, and health profiles of these individuals favors the implementation of actions specific to this age group by health providers, and helps managers to develop health indicators.

Descriptors: Aged; Public Health Nursing; Epidemiology; Health of the Elderly.

\footnotetext{
${ }^{1}$ Paper extracted from Master's Dissertation "Conhecendo o idoso na comunidade: subsídios para a equipe e para os serviços de saúde, Guarapuava - PR", presented to Universidade Estadual de Maringá, PR, Brazil.

2 RN, M.Sc. in Nursing, Professor, Universidade Estadual do Centro Oeste, Guaruapuava, PR, Brazil.

E-mail: caliopepilger@hotmail.com.

${ }_{3}^{3}$ Mathematician, Ph.D. in Mathematic, Adjunct Professor, Universidade Estadual do Centro Oeste, Guaruapuava, PR, Brazil. E-mail: menon@unicentro.irati.br.

${ }^{4}$ RN, Ph.D. in Nursing, Adjunct Professor, Universidade Estadual de Maringá, PR, Brazil. E-mail: tafmathias@uem.br.
}

Corresponding Author:

Calíope Pilge

Rua Coroados, 627, Apto. 08

Vila Carli

CEP 85040-220, Guarapuava, PR, Brasi

E-mail: caliopepilger@hotmail.com 


\title{
Características sociodemográficas e de saúde de idosos: contribuições para os serviços de saúde
}

Trata-se de estudo epidemiológico seccional com inquérito domiciliar, com o objetivo de descrever as características sociodemográficas e as condições de saúde de idosos do município de Guarapuava, PR, Brasil. A amostra do estudo foi composta por 359 idosos inscritos nas UBSs do município. As entrevistas foram realizadas de janeiro a abril de 2010, utilizando-se a seção I e II do questionário Brazil Old Age Schedule - BOAS. Os resultados demonstraram que o sexo feminino foi prevalente $(64,3 \%)$, a autopercepção de saúde foi boa para $54,6 \%$ dos idosos, as doenças mais relatadas foram hipertensão $(34,9 \%)$, diabetes mellitus $(12,4 \%)$ e artrite/artrose $(12,2 \%)$. A maioria dos idosos utiliza prótese dentária $(74,4 \%), 56,5 \%$ óculos ou lente de contato. Conclui-se que o conhecimento do perfil sociodemográfico e de saúde desses idosos favorece a implantação de ações específicas para essa faixa etária pelos profissionais de saúde que trabalham nesse município, além de auxiliar os gestores para formular indicadores de saúde.

Descritores: Idoso; Enfermagem em Saúde Pública; Epidemiologia; Saúde do Idoso.

\section{Característicassociodemográficasy desalud deancianos: contribuciones para los servicios de salud}

\begin{abstract}
Se trata de un estudio epidemiológico seccional con encuesta domiciliar con el objetivo de describir las características sociodemográficas y las condiciones de salud de ancianos del municipio de Guarapuava, PR, Brasil. La muestra del estudio fue compuesta por 359 ancianos inscritos en las UBS del municipio. Las entrevistas fueron realizadas de enero a abril de 2010 utilizando la sección I y II del cuestionario Brasil Old Age Schedule - BOAS. Los resultados demostraron que el sexo femenino fue prevalente $(64,3 \%)$, la autopercepción de salud fue buena para $54,6 \%$ de los ancianos; las enfermedades más relatadas fueron hipertensión (34,9\%), diabetes mellitus $(12,4 \%)$ y artritis/artrosis $(12,2 \%)$. La mayoría de los ancianos utiliza prótesis dentaria $(74,4 \%), 56,5 \%$ lentes o lente de contacto. Se concluye que el conocimiento del perfil sociodemográfico y de salud de estos ancianos favorece la implantación de acciones específicas, para este intervalo etario, por los profesionales de salud que trabajan en este municipio, además de auxiliar a los gestores para formular indicadores de salud.
\end{abstract}

Descriptores: Anciano; Enfermería en Salud Pública; Epidemiología; Salud del Anciano.

\section{Introduction}

Brazil has experienced important changes in its demographic profile and in its population's age structure with increased life expectancy accentuating the aging process. The advancement of technologies in the health field, greater attention to primary health care, development of public health policies directed to elderly individuals, and the new paradigm of health promotion, among other factors, have contributed to individuals achieving increasingly older ages with health(1).

A total of 697,000 individuals turned 60 years old between 2008 and 2009, which represents an increase of $3.3 \%$; the total Brazilian population increased $1 \%$ in the same period. In 2009, $11.3 \%$ of the Brazilian population was 60 years old or older in comparison to $11.1 \%$ in 2008 and $9.7 \%$ in $2004^{(2)}$.

Guaranteed access to quality health services for the elderly population is a new challenge for those planning health care delivery. Knowledge concerning the needs of elderly individuals, especially those living in their community, as well as the factors that determine the use of health services and social conditions, are important to support the planning of health care provided to this age group ${ }^{(3)}$. 
Studies addressing multidimensional knowledge concerning elderly individuals living in the community and using health services are extremely important. The study allows the detection of health problems, such as disorders that interfere in these individuals' autonomy and also make them more dependent on others to perform daily tasks. The design of appropriate actions requires one to recognize social, economic, and emotional factors that influence elderly individuals' perceptions and how they search for health services(4).

Because elderly individuals have specific characteristics, health care directed to this population requires careful assessment on the part of health providers as well as epidemiological studies designed to analyze the health and epidemiological profile of this age group in order to facilitate the identification of problems underlying their main complaints, which implies integral care. Such actions facilitate planning specific care for elderly individuals with their particularities and support the implementation of public policies intended for seniors. Hence, this study describes the socio-demographic and health characteristics of elderly individuals in the city of Guarapuava, RS, Brazil.

\section{Method}

This is an epidemiological sectional study including a household survey that addressed the socio-demographic and health conditions of elderly individuals registered in Primary Health Care (PHC) units residing in the city of Guarapuava, RS, Brazil with an estimated population of 172,128 inhabitants and 14,981 elderly individuals(5).

A list provided by the nurse responsible for all 30 PHC units in the city was used in sampling. The 359 interviewed individuals were selected among 5,508 60 years old or older individuals registered on 'forms $A$ ' from the Family Health Strategy (FHS). Forms A are registration forms used in following-up families in the Primary Care Information System.

The sample was computed through stratified proportional sampling considering the number of elderly individuals in each of the $30 \mathrm{PHC}$ units in the city through the following equation:

$$
n 0=\frac{(Z \alpha / 2)^{2}}{4 d^{2}}
$$

Where: $z \alpha / 2=z 0.025=1.96$; confidence level $=95 \% ; n=(N . n 0) /(N+n 0) ; d=$ margin of error. The 359 elderly individuals were selected through a simple and random draw, proportional to the total number of individuals registered in each $\mathrm{PHC}$ unit.
Information was obtained through questionnaires applied by interviewers to elderly individuals residing in the selected households or to the caregivers when the individuals presented an impairment compromising communication. Thirteen refused to participate in the study and a new individual was randomly drawn for each refusal.

A total of 11 interviewers were selected: undergraduate students or professionals with a bachelor's degree who were trained in four meetings of four hours each. The interviewers received information concerning the study's objective, the importance and the role of the interviewers, concepts used, structure of questions, ethical aspects and ways to approach the interviewees in their households. Among the main difficulties mentioned during data collection were: outdated addresses, difficulty locating streets, and difficulty accessing certain streets and regions of the city. Data collection began January $23^{\text {rd }} 2010$ and ended on April $4^{\text {th }} 2010$.

The Brazil Old Age Schedule(6) (BOAS) questionnaire was used to collect data. It is a multidimensional tool that covers various dimensions of elderly individuals' lives such as physical and mental aspects, daily tasks, and social and economic conditions.

BOAS is divided into nine sections and two were used in this study (I and II). The analyzed variables were: gender, educational level, marital status, family arrangements, paid job, family income, residence, main health problems, types of devices used, characteristics of oral health and health self-perception.

Interviews took an average of 47 minutes (minimum of 20 and maximum of 185 minutes). Data were directly coded in the questionnaires and stored in an Excel spreadsheet, which were then analyzed through the statistical program Estatistica. Double entry was used to check for inconsistencies later. Data were analyzed using simple frequency through the Chi-square test and Fischer's exact test.

The research project was approved by the Ethics Committee for Research Involving Human Subjects at the State University of Maringá in accordance with resolution 196/96, National Council of Health (Protocol 492/2009).

\section{Results}

Of the 359 interviewed individuals $64.4 \%$ were women and $35.6 \%$ were men with an average age of $68.8 \pm 9.09$ years, varying from 60 to 98 years old. In relation to monthly family income (per capita), the minimum income was USD 69.48 and the maximum 
was $\mathrm{R} \$ 6.567 .00$. In relation to state of origin, $91.4 \%$ of men and $92 \%$ of women were born in the state of Paraná, Brazil.

In relation to educational level, $21.4 \%$ were illiterate. Younger individuals, from 60 to 69 years old, were more educated and the 80 years old or older individuals had at most completed primary school $(5 \%$ of the total) (Table 1 ). The results concerning marital status indicate that $57.7 \%$ were married or cohabited and
$34.5 \%$ were widowed. Of the total of elderly individuals, $\mathbf{8 6 . 4 \%}$ live with a family member or caregiver, mainly in multigenerational homes: with a spouse and/or children and/or children-in-law, or with grandchildren.

A total of $56.9 \%$ of individuals in the job market were 70 to 79 years old; these individuals were already retired but kept a paid job. A total of $71.3 \%$ received up to one times the minimum wage (Table 1 ).

Table 1 - Distribution of elderly individuals according to age and socio-demographic variables. Guarapuava, PR, Brazil, 2010

\begin{tabular}{|c|c|c|c|c|c|c|c|c|}
\hline \multirow{3}{*}{ Variables } & \multicolumn{8}{|c|}{ Idade } \\
\hline & \multicolumn{2}{|c|}{$60-69$} & \multicolumn{2}{|c|}{$70-79$} & \multicolumn{2}{|c|}{80 or older } & \multicolumn{2}{|c|}{ Total } \\
\hline & $\mathbf{N}$ & $\% *$ & $\mathbf{N}$ & $\% *$ & $\mathbf{N}$ & $\%{ }^{*}$ & $\mathbf{N}$ & $\% *$ \\
\hline \multicolumn{9}{|l|}{ Gender } \\
\hline Male & 72 & 56.2 & 44 & 34.4 & 12 & 9.4 & 128 & 35.6 \\
\hline Female & 145 & 62.8 & 58 & 25.1 & 28 & 12.1 & 231 & 64.4 \\
\hline \multicolumn{9}{|l|}{ Educational level } \\
\hline None & 31 & 14.3 & 23 & 22.5 & 8 & 20.0 & 62 & 17.3 \\
\hline Primary school & 129 & 59.4 & 46 & 45.1 & 19 & 47.5 & 194 & 54.0 \\
\hline Middle School & 13 & 6.0 & 4 & 3.9 & 2 & 5.0 & 19 & 5.3 \\
\hline High school & 3 & 1.4 & 3 & 2.9 & - & - & 6 & 1.7 \\
\hline Bachelor's degree & 3 & 1.4 & - & - & - & - & 3 & 0.8 \\
\hline Do not know how to read or write & 38 & 17.5 & 26 & 25.5 & 11 & 27.5 & 75 & 20.9 \\
\hline \multicolumn{9}{|l|}{ Marital Status } \\
\hline Married/cohabitating & 144 & 66.4 & 50 & 49.0 & 13 & 32.5 & 207 & 57.7 \\
\hline Widowed & 53 & 24.4 & 46 & 45.1 & 25 & 62.5 & 124 & 34.5 \\
\hline Divorced/separated & 16 & 7.4 & 4 & 3.9 & - & - & 20 & 5.6 \\
\hline Never married & 4 & 1.8 & 2 & 2.0 & 2 & 5.0 & 8 & 2.2 \\
\hline \multicolumn{9}{|l|}{ Family arrangement } \\
\hline Lives alone & 24 & 11.1 & 14 & 13.7 & 11 & 27.5 & 49 & 13.6 \\
\hline Lives with someone & 193 & 88.9 & 88 & 86.3 & 29 & 72.5 & 310 & 86.4 \\
\hline \multicolumn{9}{|l|}{ Paid job } \\
\hline Retired and paid job & 44 & 20.3 & 58 & 56.9 & 3 & 7.5 & 105 & 29.2 \\
\hline Retired & 173 & 79.7 & 44 & 43.1 & 37 & 92.5 & 254 & 70.8 \\
\hline \multicolumn{9}{|l|}{ Per capita income } \\
\hline 0 to 1 one times the minimum wage ${ }^{\dagger}$ & 163 & 75.1 & 70 & 68.6 & 23 & 57.5 & 256 & 71.3 \\
\hline 1 to 3 times $^{\dagger}$ & 50 & 23.0 & 32 & 31.4 & 17 & 42.5 & 99 & 27.6 \\
\hline More than 3 times $^{\dagger}$ & 4 & 1.8 & - & - & - & - & 4 & 1.1 \\
\hline \multicolumn{9}{|l|}{ Residence } \\
\hline Rural area & 64 & 29.5 & 17 & 16.7 & 9 & 22.5 & 90 & 25.1 \\
\hline Urban area & 153 & 70.5 & 85 & 83.3 & 31 & 77.5 & 269 & 74.9 \\
\hline
\end{tabular}

* Percentage computed excluding unanswered or ignored variables.

+ Minimum wage at the time of the study USD $322.17 / \mathrm{mo}$.

Table 2 shows the distribution of health problems reported by the elderly individuals, expressed as frequency in relation to the total number of reported diseases; the same individual may present more than one health problem. Of the 359 elderly individuals,
$11.6 \%$ (63) reported no disease; $17.2 \%$ of which were men and $9 \%$ were women. Hypertension was the most frequently reported disease with $34.9 \%$ (30.5\% men and $37.1 \%$ women), followed by diabetes with $12.4 \%$ and arthritis/arthrosis with $12.2 \%$. 
Table 2 - Distribution of elderly individuals according to gender and main reported health problems. Guarapuava, PR, Brazil, 2010

\begin{tabular}{|c|c|c|c|c|c|c|}
\hline \multirow{2}{*}{ Health Problems } & \multicolumn{2}{|c|}{ Male } & \multicolumn{2}{|c|}{ Female } & \multicolumn{2}{|c|}{ Total } \\
\hline & $\mathbf{N}^{*}$ & $\%$ & $\mathbf{N}^{*}$ & $\%$ & $\mathbf{N}^{*}$ & $\%$ \\
\hline Arterial hypertension & 53 & 30.5 & 136 & 37.1 & 189 & 34.9 \\
\hline Diabetes mellitus & 28 & 16.1 & 39 & 10.6 & 67 & 12.4 \\
\hline Arthritis/arthrosis & 16 & 9.2 & 50 & 13.6 & 66 & 12.2 \\
\hline Heart disease & 15 & 8.6 & 32 & 8.7 & 47 & 8.7 \\
\hline Asthma/bronchitis & 8 & 4.6 & 22 & 6.0 & 30 & 5.5 \\
\hline Depression & 4 & 2.3 & 17 & 4.7 & 21 & 3.9 \\
\hline Gastritis & 5 & 2.9 & 14 & 3.8 & 19 & 3.5 \\
\hline Cholesterol & 3 & 1.7 & 13 & 3.5 & 16 & 3.0 \\
\hline Cancer & 6 & 3.4 & 6 & 1.6 & 12 & 2.2 \\
\hline Kidney diseases & 6 & 3.4 & 5 & 1.4 & 11 & 2.0 \\
\hline No disease & 30 & 17.2 & 33 & 9.0 & 63 & 11.6 \\
\hline
\end{tabular}

*Reported more than one health problem.

Another aspect related to how the interviewed elderly individuals perceived their health concerns the type of prostheses or aid devices they used. Of these, $56.5 \%$ use glasses or contact lenses (51.6\% men and
$59.3 \%$ women); $74.4 \%$ use dentures, artificial teeth or fixed bridges ( $60.2 \%$ men and $82.3 \%$ women) and $3.6 \%$ a hearing aid (Table 3 ).

Table 3 - Distribution of elderly individuals according to gender and type of aids used. Guarapuava, PR, Brazil, 2010

\begin{tabular}{|c|c|c|c|c|c|c|c|}
\hline \multirow{2}{*}{ Device } & \multicolumn{2}{|c|}{ Male } & \multicolumn{2}{|c|}{ Female } & \multicolumn{2}{|c|}{ Total } & \multirow{2}{*}{$p$ value } \\
\hline & $\mathbf{N}^{*}$ & $\%^{\dagger}$ & $\mathbf{N}^{*}$ & $\%^{\dagger}$ & $\mathbf{N}^{*}$ & $\%^{\dagger}$ & \\
\hline Glasses or contact lenses & 66 & 51.6 & 137 & 59.3 & 203 & 56.5 & 0.4516 \\
\hline False teeth, dentures or fixed bridges & 77 & 60.2 & 190 & 82.3 & 267 & 74.4 & 0.0723 \\
\hline Cane & 4 & 3.1 & 6 & 2.6 & 10 & 2.8 & 0.7773 \\
\hline Wheelchair & 3 & 2.3 & 1 & 0.4 & 4 & 1.1 & 0.1032 \\
\hline Crutch & - & - & 2 & 0.9 & 2 & 0.6 & 0.2932 \\
\hline Hearing device & 8 & 6.3 & 5 & 2.2 & 13 & 3.6 & 0.0569 \\
\hline
\end{tabular}

*Reported more than one health problem.

+ Percentages were computed not taking into account the unanswered or ignored variables.

Concerning the characteristics of the elderly individuals' oral health, we observed that $37.5 \%$ of them needed to replace their prosthesis; $73.5 \%$ reported they lacked most of their teeth $(66.2 \%$ men and $77.5 \%$ women); and $68.5 \%$ reported no problems hindering mastication (Table 4).

Table 4 - Distribution of elderly individuals according to gender and oral health characteristics. Guarapuava, PR, Brazil, 2010

\begin{tabular}{|c|c|c|c|c|c|c|}
\hline \multirow{2}{*}{ Variables } & \multicolumn{2}{|c|}{ Male } & \multicolumn{2}{|c|}{ Female } & \multicolumn{2}{|c|}{ Total } \\
\hline & $\mathbf{N}$ & $\%^{*}$ & $\mathbf{N}$ & $\%^{*}$ & $\mathrm{~N}$ & \%* \\
\hline \multicolumn{7}{|l|}{ Use a prosthetic device } \\
\hline Yes & 77 & 60.2 & 190 & 82.3 & 267 & 74.4 \\
\hline No & 51 & 39.8 & 41 & 17.7 & 92 & 25.6 \\
\hline \multicolumn{7}{|l|}{ Need to replace the prosthesis } \\
\hline Yes & 38 & 29.7 & 96 & 41.9 & 134 & 37.5 \\
\hline No & 90 & 70.3 & 133 & 58.1 & 223 & 62.5 \\
\hline
\end{tabular}


Table 4 - (continuation)

\begin{tabular}{|c|c|c|c|c|c|c|}
\hline \multirow{2}{*}{ Variables } & \multicolumn{2}{|c|}{ Male } & \multicolumn{2}{|c|}{ Female } & \multicolumn{2}{|c|}{ Total } \\
\hline & $\mathbf{N}$ & $\%^{*}$ & $\mathbf{N}$ & $\%^{*}$ & $\mathbf{N}$ & \%* \\
\hline \multicolumn{7}{|l|}{ Lack teeth } \\
\hline No & 13 & 10.2 & 21 & 9.1 & 34 & 9.5 \\
\hline Not many & 30 & 23.6 & 31 & 13.4 & 61 & 17.0 \\
\hline Most & 84 & 66.2 & 179 & 77.5 & 263 & 73.5 \\
\hline \multicolumn{7}{|c|}{ Some dental problem hindering mastication } \\
\hline Yes & 40 & 31.5 & 72 & 31.4 & 112 & 31.5 \\
\hline No & 87 & 68.5 & 157 & 68.6 & 244 & 68.5 \\
\hline
\end{tabular}

*Percentages were computed not taking into account the unanswered or ignored variables.

Current self-perception of health was considered 'good' by $54.8 \%$ and 'poor' by $31.7 \%$ of the elderly individuals. Compared to the last five years, $38.6 \%$ of the individuals perceived their health to be 'worse', $32.1 \%$ to be 'better' and $29.3 \%$ considered it to have improved. When they compared themselves to people they knew or who were the same age, $46.9 \%$ believed themselves to be in better health; $29.3 \%$ considered themselves to be in an equal condition; and $38.6 \%$ in worse condition (Table 5).

Table 5 - Distribution of elderly individuals according to gender and health perception. Guarapuava, PR, Brazil, 2010

\begin{tabular}{|c|c|c|c|c|c|c|c|}
\hline \multirow{2}{*}{ Health perception } & \multicolumn{2}{|c|}{ Male } & \multicolumn{2}{|c|}{ Female } & \multicolumn{2}{|c|}{ Total } & \multirow{2}{*}{ P-value } \\
\hline & $\mathbf{N}$ & $\%^{*}$ & $\mathbf{N}$ & $\%^{*}$ & $\mathbf{N}$ & $\%^{*}$ & \\
\hline \multicolumn{8}{|l|}{ Current health Perception } \\
\hline Great & 12 & 9.4 & 10 & 4.4 & 22 & 6.2 & - \\
\hline Good & 72 & 56.3 & 124 & 54.1 & 196 & 54.8 & 0.1036 \\
\hline Poor & 38 & 29.7 & 75 & 32.8 & 113 & 31.7 & 0.0630 \\
\hline Very poor & 6 & 4.6 & 20 & 8.7 & 26 & 7.3 & 0.0248 \\
\hline \multicolumn{8}{|l|}{ Compared to the last five years } \\
\hline Better & 36 & 28.3 & 77 & 34.2 & 113 & 32.1 & - \\
\hline About the same & 42 & 33.1 & 61 & 27.1 & 103 & 29.3 & 0.1729 \\
\hline Worse & 49 & 38.6 & 87 & 38.7 & 136 & 38.6 & 0.4895 \\
\hline \multicolumn{8}{|c|}{ Compared to people the same age } \\
\hline Better & 64 & 50.4 & 102 & 44.9 & 166 & 46.9 & - \\
\hline About the same & 38 & 29.9 & 84 & 37.0 & 122 & 34.5 & 0.1940 \\
\hline Worse & 25 & 19.7 & 41 & 18.1 & 66 & 18.6 & 0.9239 \\
\hline \multicolumn{8}{|l|}{ Satisfaction with life } \\
\hline Satisfied & 104 & 82.5 & 193 & 83.9 & 297 & 83.4 & - \\
\hline Dissatisfied & 22 & 17.5 & 37 & 16.1 & 59 & 16.6 & 0.7389 \\
\hline Perception of visual acuity & & & & & 359 & & \\
\hline Great & 9 & 7.0 & 10 & 4.3 & 19 & 5.3 & - \\
\hline Good & 60 & 46.9 & 102 & 44.2 & 162 & 45.1 & 0.3803 \\
\hline Poor & 52 & 40.6 & 89 & 38.5 & 141 & 39.3 & 0.3768 \\
\hline Very poor & 7 & 5.5 & 30 & 13.0 & 37 & 10.3 & 0.0256 \\
\hline \multicolumn{8}{|l|}{ Perception of auditory acuity } \\
\hline Great & 29 & 22.8 & 57 & 24.7 & 86 & 24.0 & - \\
\hline Good & 57 & 44.9 & 117 & 50.6 & 174 & 48.6 & 0.8766 \\
\hline Poor & 39 & 30.7 & 51 & 22.1 & 90 & 25.2 & 0.1904 \\
\hline Very poor & 2 & 1.6 & 6 & 2.6 & 8 & 2.2 & 0.6157 \\
\hline \multicolumn{8}{|l|}{ Perception of oral health } \\
\hline Great & 8 & 6.7 & 21 & 9.1 & 29 & 8.3 & - \\
\hline Good & 38 & 31.7 & 31 & 13.4 & 69 & 19.7 & 0.0128 \\
\hline Poor & 50 & 41.6 & 179 & 77.5 & 229 & 65.2 & 0.4845 \\
\hline Very poor & 24 & 20.0 & - & - & 24 & 6.8 & - \\
\hline
\end{tabular}

*Percentages were computed not taking into account the unanswered or ignored variables. 
In relation to the level of satisfaction with life, $82.7 \%$ of the elderly individuals reported satisfaction and $16.4 \%$ dissatisfaction (Table 5 ). In relation to their perception concerning visual acuity (with or without glasses), 50.4\% considered it to be 'good' and 'great', while $49.6 \%$ considered it either 'poor' or 'very poor' $(p=0.025)$. Hearing was considered 'good' by $48.6 \%$ (44.9\% men and $50.6 \%$ women) and $24 \%$ considered it 'great'. Oral health was considered 'poor' by $65.2 \%$ of the studied individuals ( $41.6 \%$ men and $77.5 \%$ women).

\section{Discussion}

Among the study's, results the greater percentage of women $(64.4 \%)$ stands out. It may be related to the greater life expectancy of women in relation to men and confirms the view related to the feminization of aging, which has been attributed to less exposure on the part of women to certain risk factors compared to men, such as those found in the work environment, a lower prevalence of smoking and alcohol consumption, differences related to attitude in the face of diseases and disabilities, and greater coverage of gynecology-obstetric care ${ }^{(7-8)}$.

We observed that $21.6 \%$ of the elderly women do not know how to read and write while $21.2 \%$ are literate, though have no formal education; only one man (1.4\%), among those 60 to 69 years old had a bachelor's degree. This context shows how low levels of education influence the lives of elderly individuals at this point of life and why so many public initiatives and non-governmental actions are designed to encourage literacy and the continuing education of adults and elderly individuals. Education influences social and economic life and also the search for health services ${ }^{(9)}$. Data from the National Household Sample Survey (PNAD) reveal that $9.4 \%$ of 60 to 64 years old Brazilian individuals are illiterate and this percentage reaches $29.4 \%$ of those 65 years old or older(2).

Widowed women predominated $(43.7 \%)$, which may be explained by the fact that elderly women were also the majority of participants in this study, due to their greater life expectancy. Another explanation is that widowed men usually find another partner, especially in advanced age ${ }^{(10)}$. Most women, once they became widowed, live by themselves, as seen in a study conducted in Korean communities, which reported 10 widowed men and 87 widowed women out of 97 elderly individuals living in 32 rural communities. The deaths of their husbands was the reason these women lived alone, which is a phenomenon with characteristics common to other communities from different countries ${ }^{(11)}$.
A total of $32.5 \%$ of women and $23.4 \%$ of men still have a paid job in addition to their retirement. Having an income reflects a positive and relevant aspect of active aging. It contributes to the family income and the elderly individual has financial autonomy in relation to health, social and eating needs ${ }^{(12)}$.

Hypertension, diabetes and arthritis/arthrosis were the most common diseases, which confirms observations from previous studies addressing the elderly population ${ }^{(13-14)}$. The frequency of self reported hypertension was $30.5 \%$ among men and $37.1 \%$ among women and represented $34.9 \%$ of the total of reported diseases. Epidemiological studies have shown not only increased prevalence of hypertension as people age, but also that its occurrence is associated with other risk factors such as lifestyle and eating habits, all of these independently associated with an increased risk of heart disease. Such a fact corroborates this study's results, which show that $8.7 \%$ of the elderly individuals reported heart disease ${ }^{(15)}$.

Despite the large literature reporting the benefits of controlling diabetes, American population surveys report an increase in the prevalence of diabetes and a decline in glycemic control in this population from 1988 to $2000^{(16)}$. Arthritis or arthrosis is the main cause of impairment in the American population and its prevalence is expected to increase with population aging(17).

In Brazil, despite its high prevalence among the elderly population, arthritis is not one of the priorities of public health. Its inclusion in the public health agenda is recommended in order to improve the diagnosis and implementation of educational programs emphasizing self-care intended to prevent impairment ${ }^{(18)}$.

In relation to the use of an aid device, this study revealed a large number of elderly individuals using glasses (56.5\%) and dental prostheses (74.4\%). Devices used to help people with some level of dependency, whether it is oral, visual, or auditory or concerning mobility are important to ensure one's autonomy and independence. The prescription of appropriate devices to aid elderly individuals who experience some level of dependency is essential to promoting and preserving their functional capacity ${ }^{(19)}$.

Health self-perception is a strong indicator concerning the health of elderly individuals because it consistently predicts the survival of this population ${ }^{(13)}$. Studies show that a 'good' health self-perception is one of the most reported indicators ${ }^{(20-21)}$. In Guarapuava, $54.6 \%$ of the interviewees reported 'good' health and $31.5 \%$ reported 'poor' health. In the context of health, 
'poor' self-perception increases the risk of mortality, while at the same time interfering with one's satisfaction with life and subjective wellbeing(22). The elderly individuals health self-perception should be acknowledged by clinicians to help the implementation of individual actions intended to promote their health condition.

Oral health was considered 'good' by $37.3 \%$ of the participants and 'poor' by $34 \%$. Oral health perception can be influenced by personal values such as the belief that some pain and impairment is inevitable with age, which explains a similar prevalence of both 'good' and 'poor' oral health. The use of some prosthesis was reported by $76 \%$ of the interviewees, information that corroborates other studies' results ${ }^{(21,23-24)}$ and suggests that lost teeth were replaced in most cases. Health perception, understood as a subjective and particular aspect of individuals and its relation to other daily aspects, deserves to be deeply investigated as well as the way these relations can guide behavior and attitudes, particularly in the senior population (21).

The studies' findings related to oral health also suggest that currently there is a lack of public health policies related to oral health accessible to this age group. There is a lack of information for this population concerning the benefits of oral rehabilitation, oral hygiene, and the importance of periodic visits to the

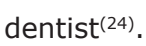

\section{Conclusion}

Collecting information from the elderly population living in the community in order to investigate socioeconomic aspects and their individual health perception is essential for public managers because it aids the implementation of strategies and public actions that improve these individuals' physical, mental and social wellbeing. These should be based not only on these individuals' rights but also on their real needs and risk factors, such as the implementation of projects to construct Day hospitals, specific hospital facilities, geriatric units with appropriate structure and installations and qualified professionals.

Even though health self-perception, visual and auditory acuity were considered to be 'good' by the interviewees, who also reported being satisfied with their lives, the city has some challenges concerning health care provided to individuals older than 60 years old. These challenges are related to the high prevalence of chronic diseases and the use of medication, which are important indicators that require constant quality care. The profile of physical and oral health found in this study related to family income and educational level draw our attention because these factors can influence the disease process, posing difficulties in accessing the health services, deficits in self-care and hindering treatment adherence.

In relation to such data, we verify the need for health professionals, especially nurses, to become better qualified and prepared to work in the context of health promotion, prevention and the rehabilitation of degenerative chronic diseases and also devise and structure preventive actions in social, cognitive and physical activities. An example of such activities are groups composed of elderly individuals that encourage a healthier social life with the implementation of recreational, physical and cultural activities aimed to enable them to change behavior and habits in the face of situations that pose a risk to their health such as hypertension, diabetes or those related to oral health.

This profile is also an essential component in the identification of the social, demographic and specific health characteristics of this population. Such information is not found in other data sources and is very important for public health plan actions directed to seniors. These are real and specific data that can be used in planning by health providers and managers to provide integral care to elderly individuals.

\section{References}

1. Bulgarelli AF, Pinto IC, Rodrigues AL Júnior, Manco ARX. Estudo das queixas sobre saúde bucal em uma população de idosos na cidade de Ribeirão Preto-SP. Rev Bras Geriatr Gerontol. 2009;12(2):175-91.

2. PNAD - Pesquisa Nacional por Amostra de Domicílios. Comentários: Indicadores do período de 2004 a 2009. 2010. [acesso 26 set 2009]. Disponível em: http://www.ibge.gov.br/home/estatistica/populacao/ trabalhoerendimento/pnad2009/comentarios2009.pdf.

3. Matos DL, Lima-Costa MF. Tendência na utilização de serviços odontológicos entre idosos brasileiros e fatores associados: um estudo baseado na Pesquisa Nacional por Amostra de Domicílios (1998 e 2003). Cad Saúde Pública. 2007;23(11):2740-8.

4. Marin MJS, Cecílio LCO. Necessidades de saúde de idosos de uma Unidade de Saúde da Família. Rev Bras Geriatr Gerontol . 2009;12(1):63-76.

5. IBGE - Instituto Brasileiro de Geografia e Estatística. Estimativas elaboradas no âmbito do Projeto UNFPA/ IBGE (BRA/4/P31A) - População e Desenvolvimento. 
Coordenação de População e Indicadores Sociais. 2010.. [acesso 8 jul 2009]. sso 2 out 2010]. Disponível em: http://tabnet.datasus.gov.br/cgi/tabcgi.exe?ibge/cnv/ poppr.def.

6. Veras R, Dutra S. Perfil do idoso brasileiro questionário BOAS. Rio de Janeiro: UERJ , UnATI; 2008. 100 p. [online]. [acesso 8 jul 2009]. Disponível em: http://www.crde-unati.uerj.br/liv_pdf/perfil.pdf.

7. Silva MJ, Lopes MVO, Aragão MFM, Moraes LA. Avaliação do grau de dependência nas atividades de vida diária em idosos da cidade de Fortaleza- Ceará. Acta Paul Enferm. 2006; 19(2):14-20.

8. Torres GV, Reis LA, Reis LA, Fernandes $\mathrm{MH}$. Características sócio-demográficas e de saúde de idosos dependentes residentes em domicílio. Rev Espaço Saúde. 2009;10(2):12-7.

9. Inouye K, Pedrazzani E. Nível de instrução, status socioeconômico e avaliação de algumas dimensões da qualidade de vida de octogenários. Rev. Latino-Am. Enfermagem. 2007; 15(n.spe):742-7.

10. Baldin CB, Fortes VLF. Viuvez feminina: a fala de um grupo de idosas. RBCEH. 2008;5(1):43-54.

11. Ain, YH, Kim, MJ. Health care needs of olderly in the rural community in Korea. Public Health Nurs. 2004;21(2):153-16. [acesso 8 dez 2010]. Disponível em: http:/www.blackweel-synergy.com/doi/pdf/10.1111/ j.0737.1209.2004.021209.x

12. WHO - World Health Organization. Envelhecimento ativo: uma política de saúde. Brasília (DF): Organização Pan - Americana de Saúde; 2005. 60 p. WHO/NMH/ $\mathrm{NPH} / 02.8$

13. Lima-costa MF, Barreto SM, Giatti L. Condições de saúde, capacidade funcional, uso de serviços de saúde e gastos com medicamentos da população idosa brasileira: um estudo descritivo baseado na Pesquisa Nacional por Amostra de Domicílios. Cad Saúde Pública. 2003;19(3):735-43.

14. Cavalcanti CL, Gonçalves MCR, Asciuti LSR, Cavalcanti AL. Prevalência de doenças crônicas e estado nutricional em um grupo de idosos brasileiros. Alayón Complicacion. Rev Salud Pública. 2009;11(6):865-77.

15. Passos VMA, Assis TD, Barreto SM. Hipertensão arterial no Brasil: estimativa de prevalência a partir de estudos de base populacional. Epidemiol Serviços de Saúde. 2006;15(1):35-45.

16. Koro CE, Bowlin SJ, Bourgeois N, Fedder DO. Glycemic control from 1988 to 2000 among U.S. adults diagnosed with type 2 diabetes: a preliminary report. Diabetes Care. 2004; 27:17-20.

17. Hootman J, Bolen J, Helmick C, Langmaid G.
Prevalence of doctor-diagnosed arthritis and arthritisattributable activity limitation - United States, 20032005. MMWR Morb Mortal Wkly Rep. 2006;55:1089-92. 18. Giacomin KC, Peixoto SV, Uchoa E, Lima-costa MF. Estudo de base populacional dos fatores associados à incapacidade funcional entre idosos na Região Metropolitana de Belo Horizonte, Minas Gerais, Brasil. Cad Saúde Pública. 2008;24(6):1260-70.

19. Jardim VCFS. Perfil epidemiológico e grau de autonomia de mulheres idosas

participantes de grupos de convivência, no município de Olinda - PE. [dissertação de mestrado]. Recife (PE): Centro de Pesquisas Aggeu Magalhães da Fundação Oswaldo Cruz; 2008. 143 p.

20. Silveira SR, Cabral GTR, Correa LB, Reis LB. Análise do perfil do idosos atendidos por um Programa de Saúde da Família do bairro Araças em Vila Velha- ES. Ciênc Saúde Colet. 2007;12(6):1683-90.

21. Benedetti TRB, Mello ALSF, Gonçalves LHS. Idosos de Florianópolis: autopercepção das condições de saúde bucal e utilização de serviços odontológicos. Ciênc Saúde Colet. 2007; 12(6):1683-90.

22. Tavares DMS, Guidetti GECB, Saúde MIBM. Características sócio-demográficas, condições de saúde e utilização de serviços de saúde por idosos. Rev Eletrônica Enferm. 2008;10(2):299-309. [acesso 10 nov 2010]. Disponível em: http://www.fen.ufg.br/revista/ 10/n2/v10n2a02.htm.

23. Ministério da Saúde (BR). Projeto SABE Brasil. Condições de saúde bucal da população brasileira 20022003: Resultados Principais. Brasília: Coordenação Nacional de Saúde Bucal; 2003.

24. Monti LM, Justi MM, Farjado RS, Zavanelli AC. Análise comparada da saúde bucal do idoso na cidade de Araçatuba. Rev Bras Geriatr Gerontol. 2006;9(2):35-47. [acesso 8 dez 2010]. Disponível em: http://revista.unati. uerj.br/scielo.php?script=sci_abstract \&pid=S1809-982 $32006000200004 \&$ Ing $=p t \& n r m=i s o \& t$ Ing $=p t$
Received: Jan. 20 th 2011 Accepted: June $22^{\text {nd }} 2011$ 